INTERACTION:Jurnal Pendidikan Bahasa: Vol. 6, No. 2: Oktober 2019

ISSN: 2406-9558; E-ISSN: 2406-9566

\title{
Improving Students Ability in Using Preposition of Place through Video as Media
}

\author{
Yuni Rahayuningsih \\ yunirahayuningsih@gmail.com
}

SMK Tunas Rajawali

\begin{abstract}
In learning English, grammar is one of significant components to mediate the system of written symbol that cannot be avoided. Tenses, preposition, to be, and articles are some aspect of grammar. Preposition is one of the important things in grammar aspects. The formulation of problem in this research is "Can video as media develop student's ability in using preposition of place?". The research design in this research is quasi experimental design. The sample of this research is students in SMK TUNAS RAJAWALI and the writer taken all students the tenth grade is 26 students. The first step of this research the writer gave pretest to measure the student abilities before doing treatment. Second give treatment the teacher usually starts the lesson by greeting the students and checking the attendance list. It is support by the result of the using this method that the teacher always greets the student when they start the lesson. The activities during the teaching and learning process the classroom. Then the teacher showing the video about preposition of place to the student's, the teacher ask the student's to watch the video about the material preposition of place, the teacher ask the students to repeat each the sentences of preposition, after that the teacher ask the students to understand the kinds of preposition of place. The last is the teacher asking the student's feeling about teaching and learning process of preposition of place by using video. By using $\mathrm{t}$ - test formulation the writer gets 16.158 and the t-table value with 0.05 with df 25 is 1.7081 . It means that t-test value is higher than $t-$ table. In other word it can be said that the alternative hypothesis (Ha) is accepted and null hypothesis (Ho) is rejected. It means that the student's ability before gave video as media is low and the student's ability after teach using video as media technique is improve, so the video as media is effective for the tenth-grade students of SMK TUNAS RAJAWALI.
\end{abstract}

Key words: Preposition of Place, Video 
INTERACTION:Jurnal Pendidikan Bahasa: Vol. 6, No. 2: Oktober 2019

ISSN: 2406-9558; E-ISSN: 2406-9566

\section{INTRODUCTION}

Preposition is one of function words in English. Preposition is one of the important things in grammar aspects. But some of the students were confused to use the right preposition of place in the sentences. English teaching involves four language skill, they are listening, speaking, reading and writing. Teaching English is very complicated in the classroom. Teachers often try to use various technique in the hope that students can understand the lesson easily.

As a teacher, it is necessary to find new teaching media to overcome the problems and not to forget to motivate the students. Some teachers used games, pictures, songs, video, real object, cartoon and movie as their teaching media in order to increase the student's creativity in learning process.

There are many media can be used to improve student's ability like audio aid, audio visual aid and etc. The writer investigated this case in the hope that it can help the teachers of English in teaching preposition of place and for the students of SMK in learning preposition of place.

\section{LITERATURE REVIEW}

\section{Previous of Study}

Nuraeni Komariah (2012), "Teaching Preposition of Place Through Contextual Teaching and Learning at the fifth grade of SDN Pondok Cabe Ilir III Pondok Cabe Tangerang Selatan". The purpose of the research is to gain information about teaching preposition of place through contextual teaching and learning at the fifthgrade students of SDN Pondok cabe Ilir III, Tangerang Selatan.

The differences of this research with the previous study is that this study learn the effect of video as media in improving student's ability in using preposition of place. But the previous study learnt the effect of contextual teaching and learning (CTL) in teaching preposition of place.

\section{METHOD}

\section{Design}

The research was conducted through quantitative research design, quasi experimental design. The design of this research is:

Table 3.1. The design of this research

\begin{tabular}{|lll|}
\hline $\mathrm{T} 1$ & $\mathrm{X}$ & $\mathrm{T} 2$ \\
\hline
\end{tabular}


INTERACTION:Jurnal Pendidikan Bahasa: Vol. 6, No. 2: Oktober 2019

ISSN: 2406-9558; E-ISSN: 2406-9566

$\mathrm{T}_{1} \quad$ : Pre-test

$\mathrm{X} \quad$ : Treatment

$\mathrm{T}_{2} \quad$ : $\quad$ Post-test (Arikunto, 2006:85)

\section{Analysis Data}

\section{T - Test formula}

The formula of $\mathrm{t}$ - test is as follows:

$\mathrm{T}$ obs $=$

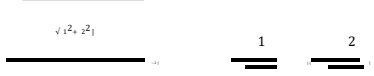

Where :

To

: Tobs

: Mean score before treatment

$=\quad$ : Mean score after treatment

n1 : The number of items (experiment group)

n2 : The number of items (control group)

$\mathrm{r} \quad$ : Correlation

$\mathrm{S}^{2} \quad$ : Varian sample 1

$\mathrm{S}^{2} \quad$ : Varian sample 2

$\mathrm{S} 1$ : Deviation sample 1

S2 : Deviation sample 2

\section{Score Formula}

Table 3.2. The seven scales interval of students score Kanwil Dikbud

\begin{tabular}{|c|c|}
\hline Score & Categories \\
\hline $9.6-10$ & Excellent \\
\hline $8.6-9.5$ & Very good \\
\hline $7.6-8.5$ & Good \\
\hline $6.6-7.5$ & Fairly good \\
\hline $5.6-6.5$ & Fair \\
\hline $3.6-5.5$ & Poor \\
\hline $0-3.5$ & Very poor \\
\hline \multicolumn{2}{|c}{} \\
\hline
\end{tabular}

\section{RESULT AND DISCUSSION}

\section{Finding}

\section{The Result of Pre-test}

A pre-test was given before doing the treatment. The result of pre-test can be seen in the table below: 
INTERACTION:Jurnal Pendidikan Bahasa: Vol. 6, No. 2: Oktober 2019

ISSN: 2406-9558; E-ISSN: 2406-9566

Table 4.1. The score distribution in pre-test:

\begin{tabular}{|c|c|c|c|}
\hline No. & Students & Pre Test (X1) & Categories \\
\hline 1. & A1 & 75 & Fairly Good \\
\hline 2. & $\mathrm{~A} 2$ & 60 & Fair \\
\hline 3. & $\mathrm{~A} 3$ & 55 & Poor \\
\hline 4. & A4 & 70 & Fairly Good \\
\hline 5. & A5 & 75 & Fairly Good \\
\hline 6. & A6 & 75 & Fairly Good \\
\hline 7. & A7 & 55 & Fair \\
\hline 8. & A8 & 50 & Poor \\
\hline 9. & A9 & 50 & Poor \\
\hline 10 & A10 & 45 & Poor \\
\hline 11. & A11 & 75 & Fairly Good \\
\hline 12. & A12 & 60 & Fair \\
\hline 13. & A13 & 55 & Poor \\
\hline 14. & A14 & 45 & Poor \\
\hline 15. & A15 & 70 & Fairly Good \\
\hline 16. & A16 & 65 & Fair \\
\hline 17. & A17 & 75 & Fairly Good \\
\hline 18. & A18 & 45 & Poor \\
\hline 19. & A19 & 75 & Fairly Good \\
\hline 20. & $\mathrm{~A} 20$ & 45 & Poor \\
\hline 21. & $\mathrm{~A} 21$ & 35 & Very Poor \\
\hline 22. & A22 & 35 & Very Poor \\
\hline 23. & A23 & 55 & Poor \\
\hline
\end{tabular}


INTERACTION:Jurnal Pendidikan Bahasa: Vol. 6, No. 2: Oktober 2019

\begin{tabular}{|r|c|c|c|}
\hline 24. & A24 & 70 & Fairly Good \\
\hline 25. & A25 & 75 & Fairly Good \\
\hline 26. & A26 & 45 & Poor \\
\hline & & ${ }_{\Sigma 1=590}$ & Fair \\
\hline
\end{tabular}

$$
\begin{aligned}
\text { Mean } \mathrm{T}_{1} & =\underline{\Sigma} \\
\sum \mathrm{S} & =1535 \\
\mathrm{~N} & =26 \\
& =\square \\
& =5.9 \quad \text { Fair }
\end{aligned}
$$

From the table above, it could be seen that the students mean score was 5.9, and it meant that the students' ability in understanding preposition of place was still fair.

\section{The Result of Post Test}

A post-test was given to know students achievement after treatment. The result of post-test can be seen in the table below:

Table 4.2. The score distribution in post - test:

\begin{tabular}{|c|c|c|c|}
\hline No. & Students & Post Test (X2) & Categories \\
\hline 1. & A1 & 85 & Good \\
\hline 2. & A2 & 75 & Fairly Good \\
\hline 3. & A3 & 75 & Fairly Good \\
\hline 4. & A4 & 85 & Good \\
\hline 5. & A5 & 95 & Very Good \\
\hline 6. & A6 & 90 & Very Good \\
\hline 7. & A7 & 70 & Fairly Good \\
\hline 8. & A8 & 70 & Fairly Good \\
\hline 9. & A9 & 65 & Fair \\
\hline 10 & A10 & 60 & Fair \\
\hline
\end{tabular}


INTERACTION:Jurnal Pendidikan Bahasa: Vol. 6, No. 2: Oktober 2019 ISSN: 2406-9558; E-ISSN: 2406-9566

\begin{tabular}{|l|l|l|c|}
\hline 11. & A11 & 85 & Good \\
\hline 12. & A12 & 80 & Good \\
\hline 13. & A13 & 70 & Fairly Good \\
\hline 14. & A14 & 70 & Fairly Good \\
\hline 15. & A15 & 90 & Very Good \\
\hline 16. & A16 & 75 & Fairly Good \\
\hline 17. & A17 & 85 & Good \\
\hline 18. & A18 & 70 & Fairly Good \\
\hline 19. & A19 & 85 & Good \\
\hline 20. & A20 & 70 & Fairly Good \\
\hline 21. & A21 & 60 & Fair \\
\hline 22. & A22 & 65 & Fair \\
\hline 23. & A23 & 70 & Fairly Good \\
\hline 24. & A24 & 90 & Very Good \\
\hline 25. & A25 & 95 & Very Good \\
\hline 26. & A26 & 60 & Fair \\
\hline & & $2=765$ & Good \\
\hline
\end{tabular}

Mean $\mathrm{T}_{1}=-\underline{-}$

$$
\begin{aligned}
\sum \mathrm{S} & =1989 \\
\mathrm{~N} & =26 \\
& =- \\
& =76.5 \text { Good }
\end{aligned}
$$

From the table above, it's known that the students mean score was 76.5, and it meant that the student's ability in understanding preposition of place was good.

\section{The Result of Using Video as Media}

Table 4.3. Of T-Test: 
INTERACTION:Jurnal Pendidikan Bahasa: Vol. 6, No. 2: Oktober 2019

ISSN: 2406-9558; E-ISSN: 2406-9566

\begin{tabular}{|l|l|l|l|}
\hline Tobs & Df & T Table & Sig. \\
\hline 16.158 & 25 & 1.7081 & .000 \\
\hline
\end{tabular}

In order to determine the $\mathrm{t}$-value is significant or not, we look at $\mathrm{t}$-table. If it was compared to t-table, in which $\mathrm{N}=26$ or the total respondents are students with the degree of freedom $(\mathrm{df})=\mathrm{N}-1=26-1=25$ in the level of significant $5 \%$ or 0.05 was got 1.7081, the value of Tobs or t test was higher than t-table value (16.158 > 1.7081). It meant that the Ho (Video as media cannot improve the student's ability in preposition of place) is rejected and Ha (Video as media can improve the student's ability in preposition of place) is accepted. There was a significant result to improve the student's ability in using preposition of place.

\section{Scoring Classification}

Table 4.4. The frequency of pre-test in percentage

\begin{tabular}{|c|c|c|}
\hline Score & Frequency & Percentage \\
\hline 35 & 2 & $8 \%$ \\
45 & 5 & $19 \%$ \\
50 & 2 & $8 \%$ \\
55 & 4 & $15 \%$ \\
60 & 2 & $8 \%$ \\
65 & 1 & $4 \%$ \\
70 & 3 & $12 \%$ \\
75 & 7 & $26 \%$ \\
\hline
\end{tabular}

Table 4.5. The frequency of post-test in percentage:

\begin{tabular}{|c|c|c|}
\hline Score & Frequency & Percentage \\
\hline 35 & 0 & $0 \%$ \\
45 & 0 & $0 \%$ \\
50 & 0 & $0 \%$ \\
55 & 0 & $0 \%$ \\
60 & 3 & $12 \%$ \\
65 & 2 & $8 \%$ \\
70 & 7 & $26 \%$ \\
75 & 3 & $12 \%$ \\
80 & 1 & $4 \%$ \\
85 & 5 & $18 \%$ \\
90 & 3 & $12 \%$ \\
95 & 2 & $8 \%$ \\
\hline
\end{tabular}


In those table we can see that pre-test lower than post-test. From the table 4.4 and table 4.5 the writer can explain that the mean score from the pre-test is five point nine (5.9) while the post-test is higher than the pre-test.

Based on the score from pre-test, and post-test, the writer could analyze them to look for the result of this research. First, the writer analyzed the students score categories from the seven-scale interval. See below:

Table 4.6. The students score categories:

\begin{tabular}{|c|c|c|c|}
\hline No. & Categories & Pre-test & Post-test \\
\hline 1. & Excellent & 0 & 0 \\
\hline 2. & Very good & 0 & 5 \\
\hline 3. & Good & 0 & 6 \\
\hline 4. & Fairly good & 10 & 10 \\
\hline 5. & Fair & 4 & 5 \\
\hline 6. & Poor & 10 & 0 \\
\hline 7. & Very poor & 2 & 0 \\
\hline
\end{tabular}

In post-test they increased the score until there were not students who got the very poor and poor score.

In additional, the result could be seen by analyzing the score of each test. We could compare them to know whether the score was increasing or not.

Table 4.7. The comparing score

\begin{tabular}{|c|c|c|}
\hline Each score & Mean score & Note \\
\hline Pre-test & 5.9 & Fair \\
\hline Post-test & 76,5 & Good \\
\hline
\end{tabular}

The table above shows that the mean score increased in each test. In pre-test they got fair score, and post-test they got good score.

Based on the chart above, it showed that students always had improvement in preposition of place from fair score to good score. The score indicates that the use of video as media could improve the student's ability to use preposition of place. 
INTERACTION: Jurnal Pendidikan Bahasa: Vol. 6, No. 2: Oktober 2019

ISSN: 2406-9558; E-ISSN: 2406-9566

\section{Discussion}

The teacher now is expected to use of video for mass media teaching or learning. A good instrument towards achieving this is television which process seeing and hearing qualities that makes more effective teaching and learning. Based on the score from pre-test and post-test the writer could analyze them to look for the result of this research. The result of pre-test was 59 and post-test was 76.5 that the mean score was increasing in each test. In pre-test they got fair score, and post-test they got good score.

Based on the chart above, it showed that students always got improvement in using preposition of place from fair score to good score. The score indicates that the use of video can improve the students in using preposition of place. By using $\mathrm{T}$ test formulation If it was compared to t-table, in which $\mathrm{N}=26$ or the total respondent are students with the degree of freedom (df) $=\mathrm{N}-1=26-1=25$ in the level of significant $5 \%$ or 0,05 was got 1.7081 , that value of Tobs was higher than t-table $(16.158>1.7081)$ it mean that the Ho (video as media cannot improve the students ability in using preposition of place) rejected and $\mathrm{Ha}$ ( video as media can improve the students ability in using preposition of place) was accepted.

On the finding of the study it could be concluded that teaching using video as media was successful and could run well in the classroom. It also could give students the opportunities to be active in the teaching learning process.

\section{CONCLUSION}

Based on the result of the data analyze, it could be concluded that the use of video as media was effective. It was proved by the result of the students' mean score in pretest, and post-test. By using $\mathrm{t}$ - test formulation the writer gets 16.158 and the $\mathrm{t}$-table value with $0.05(95 \%)$ with df 25 is 1.7081 . It means that $t$-test value was higher than t-table. In other word it could be said that the alternative hypothesis (Ha) was accepted and null hypothesis (Ho) was rejected. So the video as media in teaching was effective for the students' of SMK TUNAS RAJAWALI.

\section{REFERENCES}

Amato, Richards, Patricia A., Making it Happen, New York: Longman, 1988

Arikunto, Suharsimi. 2006. Metodelogi Penelitian. Yogyakarta: Bina Aksara.

Arikunto, Suharsimi, Penelitian Tindakan Kelas, Jakarta: Bumi Aksara, 2009

Billow, F.L., Teaching Techniques of Language Teaching, London: Longman Group Limited, 1961

Bruce, Joyce R. and Harootunian Berj., The Structure of Teaching. Chicago: Science Research Associties, Inc, 1967 
INTERACTION: Jurnal Pendidikan Bahasa: Vol. 6, No. 2: Oktober 2019 ISSN: 2406-9558; E-ISSN: 2406-9566

Curtain, Helena Anderson and Carol Ann Pesola, Language and Children-Making the Match: Foreign Language Instruction in the Elementary School, AddisonWesley Publishing Company, Inc, 1988

Djamarah, Syaiful Bahri and Aswan Zain, Strategi Belajar Mengajar, Jakarta: P.T Rineka Cipta, 2006

Farmer, Majorie and Friends, Composition and Grammar II, Steps in the Writing Process,Texas: Laidlaw Brothers Publisher, 1985

Foley, Mark and Diane Hall. Advanced Learner's Grammar: A Self-Study Reference and Practice Book with Answer, Harlow: Longman, 2003

Frank, Marcella, Modern English. A Practical Reference Guide, Englewood cliffs New Jersey: Prentice Hall, inc, 1972.

Greenbaum, Sidney and Randolph Quirk, A Student's Grammar of the English Language, Harlow: Longman, 1990

Harmer, Jeremy, The Practice of English Language Teaching Third Edition, Harlow: Longman, 2001

Jalala, Ismul, Cepat Pintar Bahasa Inggris Prepositions, Jakarta: P.T. Polytama Citra Media, 2000 (translated by the writer)

Larsen-Freeman, Diane, Techniques and Principles in Language Teaching, China:

Oxford University Press, 2000

Mahmud, Nasrun Drs., English for Muslim University Students Third Edition, Jakarta:

Pusat Bahasa dan Budaya Universitas Islam Negeri, 2003

Meltzer, David E., The Relationship between Mathematics Preparation and Conceptual Learning Gains in Physics: A Possible Hidden Variable in Diagnostic Pretest Scores, Lowa: Department of Physics and Astronomy, 2008. Mills, Geoffrey E, Action Research: A Guide for the Teacher Researcher, New Jersey:

Merrill Prentice Hall, 2003ss

Nuraeni Komariah (2012), Teaching Preposition of Place Through Contextual Teaching and Learning at the fifth grade of SDN Pondok Cabe Ilir III Pondok Cabe Tangerang Selatan. 
INTERACTION: Jurnal Pendidikan Bahasa: Vol. 6, No. 2: Oktober 2019 ISSN: 2406-9558; E-ISSN: 2406-9566

Oller, John W. and Patricia A. Richard - Amato, Method that Work a Smorgasbord of Idea of Language Teacher, Cambridge: New Bury House Publisher, Inc, 1983

Oxford, Rebecca L., Language Learning Strategy. What Every Teacher Should Know,Boston: Heinle and Heinle Publishers, 1990

Richards, Jack C. and Theodore S. Rodgers, Approach and Method in Language Teaching, New York: Cambridge University Press, 1986

Sudijono, Anas, Pengantar Statistik Pendidikan, Jakarta: P.T Raja Grafindo Persada, 2008 Sudjana, Metode Statistika, Bandung: P.T Tarsito, 2002

Thomson, A.J and A.V Martinet, A Practical English Grammar, London: Oxford University Press, 1968

Wallace, Michael J., Action Research for Language Teachers, Cambridge: Cambridge University Press, 2006 